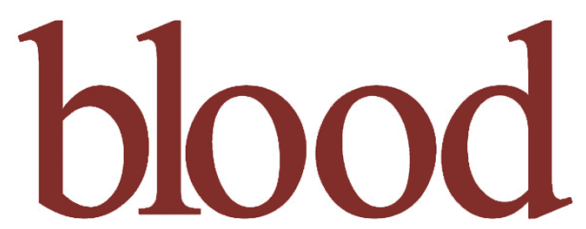

2010 116: 4492-4500

Prepublished online Jul 28, 2010;

doi:10.1182/blood-2009-12-260828

\title{
ATP secreted by endothelial cells blocks CX3CL1-elicited natural killer cell chemotaxis and cytotoxicity via P2Y 11 receptor activation
}

Stefania Gorini, Giulia Callegari, Giulia Romagnoli, Caterina Mammi, Domenico Mavilio, Giuseppe Rosano, Massimo Fini, Francesco Di Virgilio, Sara Gulinelli, Simonetta Falzoni, Andrea Cavani, Davide Ferrari and Andrea la Sala

Updated information and services can be found at:

http://bloodjournal.hematologylibrary.org/cgi/content/full/116/22/4492

Articles on similar topics may be found in the following Blood collections:

Immunobiology (4273 articles)

Vascular Biology (189 articles)

Information about reproducing this article in parts or in its entirety may be found online at:

http://bloodjournal.hematologylibrary.org/misc/rights.dt|\#repub_requests

Information about ordering reprints may be found online at:

http://bloodjournal.hematologylibrary.org/misc/rights.dtl\#reprints

Information about subscriptions and ASH membership may be found online at:

http://bloodjournal.hematologylibrary.org/subscriptions/index.dtl

Blood (print ISSN 0006-4971, online ISSN 1528-0020), is published semimonthly by the American Society of Hematology, 1900 M St, NW, Suite 200, Washington DC 20036.

Copyright 2007 by The American Society of Hematology; all rights reserved.

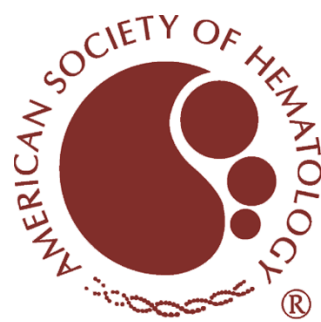




\title{
ATP secreted by endothelial cells blocks $\mathrm{CX}_{3}$ CL1-elicited natural killer cell chemotaxis and cytotoxicity via $\mathrm{P} 2 \mathrm{Y}_{11}$ receptor activation
}

\author{
*Stefania Gorini, ${ }^{*}$ Giulia Callegari, ${ }^{2}$ Giulia Romagnoli, ${ }^{3}$ Caterina Mammi, ${ }^{4}$ Domenico Mavilio, ${ }^{5}$ Giuseppe Rosano, ${ }^{4}$ \\ Massimo Fini, ${ }^{1}$ Francesco Di Virgilio, ${ }^{2}$ Sara Gulinelli, ${ }^{2}$ Simonetta Falzoni, ${ }^{2}$ Andrea Cavani, ${ }^{6}$ Davide Ferrari, ${ }^{2}$ and \\ Andrea la Sala ${ }^{1}$ \\ ${ }^{1}$ Istituto di Ricovero e Cura a Carattere Scientifico (IRCCS), San Raffaele Pisana, Rome, Italy; ${ }^{2}$ University of Ferrara, Ferrara, Italy; ${ }^{3}$ Istituto Superiore di Sanità,

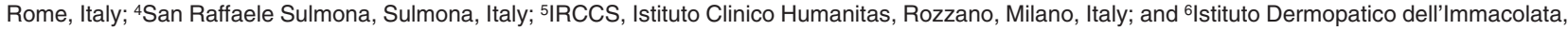 \\ IRCCS, Rome, Italy
}

\begin{abstract}
Endothelial cells (ECs) represent a major source of actively secreted adenosine triphosphate (ATP). Natural killer (NK) cells can mediate vascular injury in several pathologic conditions, including cytomegalovirus infection and vascular leak syndrome. We studied NKcell expression of P2 receptors and the role of these nucleotide receptors in the regulation of endothelial-NK cell crosstalk. NK cells from healthy subjects expressed $P 2 Y_{1,2,4,6,11,12,13,14}$ and $P 2 X_{1,4,5,6,7}$ receptors. NK cells stimulated with ATP,
\end{abstract}

but not uridine triphosphate, increased intracellular $\mathrm{Ca}^{2+}$ and chemokinesis. Moreover, ATP, but not uridine triphosphate, inhibited NK chemotaxis in response to $\mathrm{CX}_{3} \mathrm{CL1}$, whereas chemotaxis to $\mathrm{CXCL12}$ was increased. $\mathrm{CX}_{3} \mathrm{CL} 1$ elicited killing of human umbilical vein ECs and human coronary artery ECs by NK cells. However, in the presence of ATP, $\mathrm{CX}_{3} \mathrm{CL} 1$ failed to stimulate killing of ECs. Such inhibitory effect was lost on exogenous addition of the ATP-hydrolyzing enzyme apyrase or by pharmacologic in- hibition of the $P 2 Y_{11} R$, and correlated with increased intracellular cyclic adenosine monophosphate concentrations induced by ATP or other $P 2 Y_{11} R$ agonists, including $\mathrm{NAD}^{+}$. Extracellular ATP regulates NK-cell cytotoxicity via $\mathrm{P}_{2} \mathrm{Y}_{11} \mathrm{R}$ activation, protecting ECs from $\mathrm{CX}_{3} \mathrm{CL} 1$-elicited NK cell-mediated killing. These findings point out the $P 2 Y_{11} R$ as a potential target for pharmacologic intervention aimed at reducing NK-mediated vascular injury. (Blood. 2010;116(22):4492-4500)

\section{Introduction}

Nucleotides represent a class of molecules endowed with the ability to actively modulate specific cell processes. ${ }^{1}$ Nucleotides are released physiologically, as well as a consequence of cell damage, cell stress, bacterial, and parasite infection, ${ }^{2}$ and bind to specific plasma membrane receptors, named $\mathrm{P} 2$ receptors $(\mathrm{P} 2 \mathrm{R})$, widely distributed in eukaryotic cells. Intracellular pathways activated by P2Rs depend on the cell type, P2R subtypes expressed, and kind/amount of released nucleotide. Two P2 receptor subfamilies have been described so far and named P2YR and P2XR. ${ }^{3-5}$

$\mathrm{P} 2 \mathrm{XR}$ are ligand-gated ion channels selective for monovalent and divalent cations. Seven different monomers have been cloned so far and named P2 $\mathrm{X}_{1} \mathrm{R}$ to $\mathrm{P} 2 \mathrm{X}_{7} \mathrm{R}$. Differently from P2YR, the amino- and carboxyl-terminal domains of the P2XR subtypes are both cytoplasmic. On stimulation with adenosine triphosphate (ATP), P2XR subunits aggregate to form homomultimers or, in some cases, heteromultimers. ${ }^{5}$ They are expressed in mammalian sensory neurons, smooth muscle cells, fibroblasts, megakaryocytes, platelets, lymphocytes, macrophages, and dendritic cells. ${ }^{6}$ P2YR are 7 membrane-spanning, G-protein-coupled receptors whose activation triggers generation of inositol 1,4,5-trisphosphate and release of $\mathrm{Ca}^{2+}$ from the intracellular stores. Eight P2Y subtypes have been cloned so far $\left(\mathrm{P} 2 \mathrm{Y}_{1} \mathrm{R}, \mathrm{P} 2 \mathrm{Y}_{2} \mathrm{R}, \mathrm{P} 2 \mathrm{Y}_{4} \mathrm{R}, \mathrm{P} 2 \mathrm{Y}_{6} \mathrm{R}\right.$, $\mathrm{P}_{2} \mathrm{Y}_{11} \mathrm{R}, \mathrm{P} 2 \mathrm{Y}_{12} \mathrm{R}, \mathrm{P} 2 \mathrm{Y}_{13} \mathrm{R}$, and $\left.\mathrm{P} 2 \mathrm{Y}_{14} \mathrm{R}\right){ }^{7} \mathrm{P} 2 \mathrm{YR}$ are expressed in platelets, mucosal cells, monocytes, macrophages, dendritic cells, neurons, smooth and striated muscle cells, etc. They are activated by different ligands depending on given subtype. $\mathrm{P} 2 \mathrm{Y}_{1} \mathrm{R}, \mathrm{P} 2 \mathrm{Y}_{11} \mathrm{R}$, $\mathrm{P} 2 \mathrm{Y}_{12} \mathrm{R}$, and $\mathrm{P} 2 \mathrm{Y}_{13} \mathrm{R}$ are activated by ATP or adenosine diphosphate (ADP). $\mathrm{P} 2 \mathrm{Y}_{2} \mathrm{R}$ is activated both by uridine triphosphate (UTP) and ATP; $\mathrm{P} 2 \mathrm{Y}_{4} \mathrm{R}$ and $\mathrm{P} 2 \mathrm{Y}_{6} \mathrm{R}$ have UTP and UDP as agonists, whereas UDP-glucose activates the $\mathrm{P} 2 \mathrm{Y}_{14} \mathrm{R}$ subtype.

NK cells are bone marrow-derived lymphocytes that represent $5 \%$ to $10 \%$ of circulating peripheral blood mononuclear cells and contribute to the innate immune response by exerting cytolytic activity against virally infected and neoplastic cells and by secreting cytokines and chemokines. NK cells have been found in the advanced atherosclerotic lesions of human arteries as well as in the deep intima of diabetic patients. ${ }^{8}$ Moreover, NK cells are thought to mediate, at least in part, vascular damage occurring in vascular leak syndrome (VLS) ${ }^{9}$ and cytomegalovirus infection. ${ }^{10} \mathrm{In}$ such conditions, $\mathrm{CX}_{3} \mathrm{CL} 1$ expressed by ECs recruits $\mathrm{NK}$ cells bearing $\mathrm{CX}_{3} \mathrm{CR} 1$ and stimulates excessive $\mathrm{NK}$ cell cytolytic activity leading to vascular damage. ${ }^{11} \mathrm{CX}_{3} \mathrm{CL} 1$ is the only known member of the $\mathrm{CX}_{3} \mathrm{C}$ chemokine family containing the cysteine motif $\mathrm{C}-\mathrm{X}-\mathrm{X}-\mathrm{X}-\mathrm{C}$. Expression of $\mathrm{CX}_{3} \mathrm{CL} 1$ on endothelial cells (ECs) is induced by inflammatory cytokines, such as tumor necrosis factor- $\alpha$ (TNF- $\alpha$ ), interleukin-1 (IL-1), and interferon- $\gamma$, and plays a relevant role in leukocyte adhesion to the endothelium and transmigration in the inflamed tissue. Two isoforms of
Submitted December 24, 2009; accepted July 25, 2010. Prepublished online as Blood First Edition paper, July 28, 2010; DOI 10.1182/blood-2009-12-260828.

${ }^{*}$ S. Gorini and G.C contributed equally to this study.

The online version of this article contains a data supplement.
The publication costs of this article were defrayed in part by page charge payment. Therefore, and solely to indicate this fact, this article is hereby marked "advertisement" in accordance with 18 USC section 1734.

C 2010 by The American Society of Hematology 
$\mathrm{CX}_{3} \mathrm{CL} 1$ have been described. As a membrane-anchored protein, $\mathrm{CX}_{3} \mathrm{CL} 1$ works as adhesion molecule strengthening leukocyte-EC interaction. As a secreted glycoprotein, $\mathrm{CX}_{3} \mathrm{CL} 1$ functions as a potent chemoattractant for $\mathrm{CX}_{3} \mathrm{CR} 1$-bearing cells, including $\mathrm{T}$ cells, monocytes, and $\mathrm{NK}$ cells. Moreover, $\mathrm{CX}_{3} \mathrm{CR} 1$ triggering by both soluble and membrane-bound isoforms, stimulates cytolytic activity of $\mathrm{NK}$ cells and $\mathrm{CD} 8^{+}$cytotoxic $\mathrm{T}$ cells on their way to the inflamed tissue. ${ }^{12}$

To date, the pattern of $\mathrm{P} 2 \mathrm{R}$ expressed by NK cells has not been characterized. Here we show, for the first time, the expression profile of $\mathrm{P} 2 \mathrm{R}$ by $\mathrm{NK}$ cells and the effect of extracellular nucleotides on NK-EC cross-talk.

\section{Methods}

\section{Reagents and antibodies}

ATP and UTP were obtained from Roche Molecular Biochemicals. Mouse anti-human fluorochrome-conjugated antibodies specific for CD56, CD16, CXCR4, and isotype control mouse immunoglobulin (Ig) were from BD Biosciences; monoclonal antibody $(\mathrm{mAb})$ anti- $\mathrm{CX}_{3} \mathrm{CR} 1$ was obtained from MBL International. Recombinant human (rh) CXCL12, rhIL-2, and rhCX $_{3}$ CL1 were purchased from PeproTech. NF157 and NF023 were purchased from Tocris Bioscience and MRS2159 from Sigma-Aldrich.

\section{Cells and cell culture}

Peripheral blood mononuclear cells were isolated from healthy volunteers by Ficoll-Paque PLUS (GE Healthcare) density-gradient centrifugation. NK cells were isolated by negative immunomagnetic selection using Human NK Cell Enrichment cocktail (StemCell Technologies). NK-cell populations used in all experiments were more than $90 \%$ pure as confirmed by flow cytometric analysis. NK cells were maintained in RPMI 1640 growth medium containing $10 \%$ of fetal bovine serum, $1 \%$ L-glutamine, $50 \mathrm{IU} / \mathrm{mL}$ penicillin, and $50 \mu \mathrm{g} / \mathrm{mL}$ streptomycin (complete medium). The cell line K562 was obtained from ATCC. Human umbilical vein ECs (HUVECs) and human coronary artery ECs (HCAECs) were obtained from Lonza.

\section{Reverse-transcriptase polymerase chain reaction}

Total RNA was isolated from NK cells by TRIzol (Invitrogen). A total of $1 \mu \mathrm{g}$ of RNA was retro-transcribed using random primers and incubated with $200 \mathrm{U}$ of M-MLV-RT. cDNAs were then subjected to polymerase chain reaction. Primer pairs sequences for P2XR and P2YR subtypes and polymerase chain reaction conditions were previously described. ${ }^{13}$

\section{Cytosolic $\mathrm{Ca}^{2+}$ concentration measurements}

Cells $\left(1 \times 10^{7} / \mathrm{mL}\right)$ were loaded with fura-2/AM $(4 \mu \mathrm{M})$ for 15 minutes at $37^{\circ} \mathrm{C}$ in a saline solution containing: $125 \mathrm{mM} \mathrm{NaCl}, 5 \mathrm{mM} \mathrm{KCl}, 1 \mathrm{mM}$ $\mathrm{MgSO}_{4}, 1 \mathrm{mM} \mathrm{Na}_{2} \mathrm{HPO}_{4}, 5.5 \mathrm{mM}$ glucose, $5 \mathrm{mM} \mathrm{NaHCO}_{3}, 1 \mathrm{mM} \mathrm{CaCl}_{2}$, and 20mM N-2-hydroxyethylpiperazine- $\mathrm{N}^{\prime}$-2-ethanesulfonic acid ( $\mathrm{pH} 7.4$ with $\mathrm{NaOH}$ ). Cells were rinsed and incubated in $\mathrm{a} \mathrm{Na}^{+}$-free saline solution (300mM sucrose, $1 \mathrm{mM} \mathrm{K}_{2} \mathrm{HPO}_{4}, 1 \mathrm{mM} \mathrm{MgSO}_{4}, 5.5 \mathrm{mM}$ glucose, $1 \mathrm{mM}$ $\mathrm{CaCl}_{2}$, and 20mM N-2-hydroxyethylpiperazine- $\mathrm{N}^{\prime}$-2-ethanesulfonic acid, $\mathrm{pH} 7.4$, with $\mathrm{KOH}$ ) in a temperature-controlled magnetically stirred cuvette at $37^{\circ} \mathrm{C} .\left[\mathrm{Ca}^{2+}\right]_{\mathrm{i}}$ changes were measured with a PerkinElmer fluorometer (PerkinElmer Inc). The excitation wavelength was at 340 to $380 \mathrm{~nm}$, and emission at $510 \mathrm{~nm} . \mathrm{Ca}^{2+}$ concentration was calculated using the FLwinlab software (PerkinElmer Inc). ${ }^{14}$

\section{Flow cytometric analysis of NK cells}

Cells were incubated with fluorochrome-conjugated Abs for 20 minutes at $4^{\circ} \mathrm{C}$, washed and resuspended in fluorescence-activated cell sorter buffer. Cells were analyzed using a FACSCalibur flow cytometer (BD Biosciences). Results are shown as net arithmetical mean fluorescence inten- sity, calculated by subtracting the mean fluorescence obtained with isotype-matched control Ig from the mean fluorescence measured by mAbs.

\section{Migration assays}

Chemotaxis was evaluated by measuring migration through $5-\mu \mathrm{m}$ pore polycarbonate filters in 24-well transwell chambers. Different concentrations of chemokines and/or nucleotides were added in the bottom chamber, and $2 \times 10^{5} \mathrm{NK}$ cells were resuspended in $0.5 \%$ bovine serum albumin containing RPMI 1640 in the top chamber. Cells were allowed to migrate into the bottom chamber for 60 minutes at $37^{\circ} \mathrm{C}$, harvested and counted using a FACSCalibur device for 90 seconds at a flow rate of $60 \mu \mathrm{L} / \mathrm{min}$. Results are shown as migration index, representing the ratio between cells migrated in the presence of indicated stimuli and cells migrated in response to medium alone.

\section{Cytotoxicity assay}

K562 cells were incubated with $120 \mu \mathrm{Ci}$ of $\mathrm{Na}_{2}\left({ }^{51} \mathrm{Cr}\right) \mathrm{O}_{4}$ (GE Healthcare), washed, and cocultured at $5 \times 10^{3}$ cells/well in 96-well microtiter plates with NK cells in triplicate at the indicated effector/target ratios. After 4-hour incubation at $37^{\circ} \mathrm{C}$, supernatants were harvested, and radioactivity measured using a $\gamma$-counter.

In NK-EC cytotoxicity assays, HUVECs or HCAECs were resuspended at $1 \times 10^{6}$ cells $/ \mathrm{mL}$. In some experiments, cell suspension was depleted of dead cells by immunomagnetic beads (Miltenyi Biotec). ECs were then incubated with $15 \mu \mathrm{M}$ calcein-AM (Invitrogen) for 30 minutes at $37^{\circ} \mathrm{C}$. After 2 washes, cells were seeded at $5 \times 10^{3}$ cells/well in 96 -well microtiter plates with NK cells in triplicate at the indicated effector/target ratios. After 4-hour incubation, $75 \mu \mathrm{L}$ of supernatant was transferred into 96-well optical plate and fluorescence measured using a Tecan Infinite fluorometer. Maximal and spontaneous release from target cells was obtained plating target cells in $0.2 \mathrm{~mL}$ of complete medium with or without $1 \%$ Triton $\mathrm{X}-100$, respectively. Specific cell lysis was calculated as follows: lysis $(\%)=[($ experimental release - spontaneous release $) /($ maximum release - spontaneous release) $] \times 100$. Spontaneous release was in each experiment less than $8 \%$ of the maximum. NK cells were stimulated with UTP, ATP, or ATP analogs for 1 hour and extensively washed before coculture with target cells.

\section{Intracellular cAMP quantification}

Cyclic adenosine monophosphate (cAMP) assays were performed using a cAMP direct immunoassay kit (BioVision) following the manufacturer's instructions. Briefly, freshly extracted NK cells $\left(8 \times 10^{6} /\right.$ well $)$ were left untreated or incubated with $100 \mu \mathrm{M}$ ATP for 15 minutes with or without 30 minutes of pretreatment with $100 \mu \mathrm{M}$ NF175, $10 \mu \mathrm{M}$ MRS2159, or $1 \mu \mathrm{M}$ NF023. Cells were harvested washed, lysed, and centrifuged. Supernatants and standards provided with the kit assessed in triplicate in a protein G-coated assay plate and incubated with anti-cAMP pAb for 1 hour at room temperature. cAMP-horseradish peroxidase was then added to samples and incubated for 1 hour at room temperature; wells were extensively washed before the addition of horseradish peroxidase developer solution and further incubation for 1 hour. Reactions were stopped adding $1 \mathrm{~N} \mathrm{HCl}$ and optical densities read immediately at $450 \mathrm{~nm}$.

\section{Results}

\section{NK cells express members of the $\mathrm{P} 2 \mathrm{X}$ and $\mathrm{P} 2 \mathrm{Y}$} receptor subfamilies

Freshly isolated NK cells from healthy donors were studied for the expression of mRNA encoding for $\mathrm{P} 2 \mathrm{R}$. Discrete amounts of mRNA were detected for $\mathrm{P} 2 \mathrm{X}_{1} \mathrm{R}, \mathrm{P} 2 \mathrm{X}_{4} \mathrm{R}, \mathrm{P} 2 \mathrm{X}_{5} \mathrm{R}, \mathrm{P} 2 \mathrm{X}_{6} \mathrm{R}, \mathrm{P} 2 \mathrm{X}_{7} \mathrm{R}$ and $\mathrm{P} 2 \mathrm{Y}_{1} \mathrm{R}, \mathrm{P} 2 \mathrm{Y}_{2} \mathrm{R}, \mathrm{P} 2 \mathrm{Y}_{4} \mathrm{R}, \mathrm{P} 2 \mathrm{Y}_{6} \mathrm{R}, \mathrm{P} 2 \mathrm{Y}_{11} \mathrm{R}, \mathrm{P} 2 \mathrm{Y}_{12} \mathrm{R}, \mathrm{P} 2 \mathrm{Y}_{13} \mathrm{R}$, $\mathrm{P} 2 \mathrm{Y}_{14} \mathrm{R}$ subtypes as shown in Figure $1 \mathrm{~A}$. On the contrary, $\mathrm{P} 2 \mathrm{X}_{2} \mathrm{R}$ and $\mathrm{P} 2 \mathrm{X}_{3} \mathrm{R}$ mRNAs were not expressed in NK cells from any of the donors studied (data not shown; and supplemental Figure 1, 
A
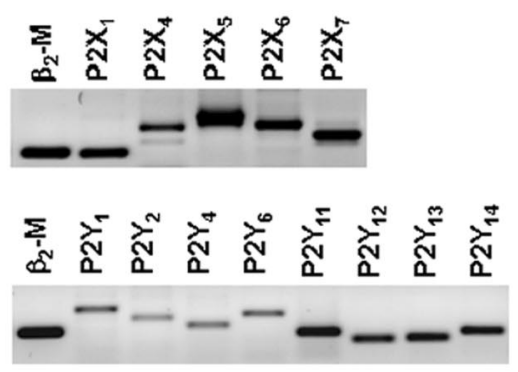

C

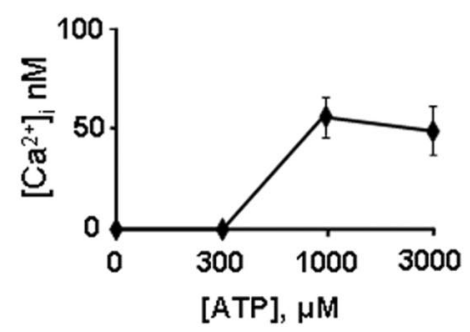

E

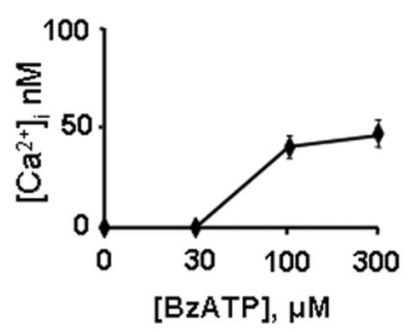

B

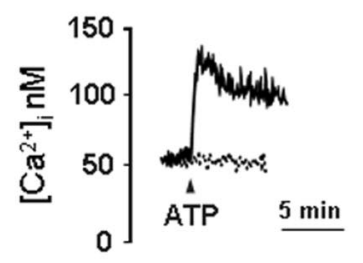

D

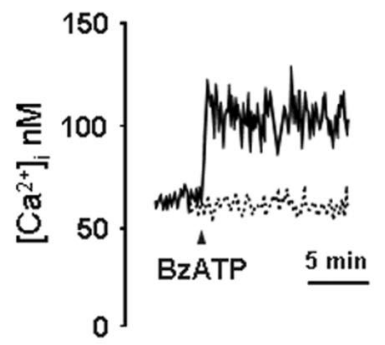

Figure 1. NK cells express functional P2Rs. (A) Expression profile of mRNA encoding P2XR and P2YR and the housekeeping gene $\beta 2$ microglobulin ( $\beta 2-\mathrm{M})$ in freshly isolated NK cells, 1 representative experiment of 4 is shown. (B,D) Calcium signal in NK cells stimulated with extracellular nucleotides. Cells were stimulated with $1 \mathrm{mM}$ ATP (B) or $300 \mu \mathrm{M}$ BzATP (D) in the presence (continuous line) or absence (dashed line) of extracellular $\mathrm{Ca}^{2+}$ For $\mathrm{Ca}^{2+}$-free conditions, $0.5 \mathrm{mM}$ ethyleneglycoltetraacetic acid was added to the $\mathrm{Ca}^{2+}$-free saline solution to chelate contaminating $\mathrm{Ca}^{2+}$. Dose-dependency curves for ATP- (C) or BzATP-induced (E) $\mathrm{Ca}^{2+}$ response are shown. (F) NK cells were incubated in the presence of the following P2 antagonists/inhibitors: KN62 (100nM, for

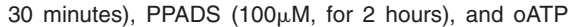
$(600 \mu \mathrm{M}$ for 1.5 hours). Cells were rinsed (oATP and PPADS) and stimulated with $300 \mu \mathrm{M}$ BzATP. One representative experiment of at least 5 similar is shown $(B, D, F)$. Data are mean $\pm S D$ of at least 4 independent experiments $(\mathrm{C}, \mathrm{E})$. available on the Blood Web site; see the Supplemental Materials link at the top of the online article).

\section{$\mathrm{Ca}^{2+}$ responses induced by P2Rs expressed by NK cells}

Expression of P2R by NK cells was confirmed by pharmacologic analysis. Binding of extracellular nucleotides to $\mathrm{P} 2 \mathrm{R}$ elicits an increase in the intracellular $\mathrm{Ca}^{2+}$ concentration $\left(\left[\mathrm{Ca}^{2+}\right]_{\mathrm{i}}\right)$ that is known to cause cellular actin polymerization, which is causally linked to cell motility (chemotaxis, chemokinesis). We therefore studied $\mathrm{Ca}^{2+}$ signaling in nucleotide-stimulated NK lymphocytes. Cells were loaded with the fluorescent $\mathrm{Ca}^{2+}$ indicator fura-2/AM, and intracellular $\mathrm{Ca}^{2+}$ changes were monitored by fluorometric analysis. Stimulation of NK cells with nucleotides in a standard (ie, $\mathrm{Na}^{+}$-containing, "Cystolic $\mathrm{Ca}^{2+}$ concentration measurements") saline solution did not induce an appreciable $\mathrm{Ca}^{2+}$ signal (not shown). It is known that $\mathrm{Na}^{+}$and $\mathrm{Ca}^{2+}$ compete for the entry through P2XR channels. ${ }^{15}$ To avoid competition between the 2 ions thus amplifying $\mathrm{Ca}^{2+}$ responses, $\left[\mathrm{Ca}^{2+}\right]_{\mathrm{i}}$ changes were measured in cells incubated in a $\mathrm{Na}^{+}$-free saline solution (ie, where $\mathrm{Na}^{+}$was replaced by sucrose, "Cystolic $\mathrm{Ca}^{2+}$ concentration measurements"). Figure 1B shows that ATP triggered in NK cells a spiking
$\left[\mathrm{Ca}^{2+}\right]_{\mathrm{i}}$ increase followed by a sustained plateau $\left(\Delta \mathrm{Ca}^{2+}=54.2 \mathrm{nM} \pm 12.8\right)$; although in the absence of the extracellular cation, $\mathrm{Ca}^{2+}$ peak and plateau were absent (dashed line), indicating that the great (if not all) $\mathrm{Ca}^{2+}$ ions contributing to the ATP-induced $\left[\mathrm{Ca}^{2+}\right]_{\mathrm{i}}$ increase derived from influx through the P2XR channels and not from the intracellular $\mathrm{Ca}^{2+}$ stores (P2YRmediated response). Figure $1 \mathrm{C}$ shows that ATP threshold concentration for the $\mathrm{Ca}^{2+}$ response was quite high (ie, $\sim 300 \mu \mathrm{M}$ ), whereas the maximal response was obtained with $1 \mathrm{mM}$ ATP. Interestingly, $\alpha, \beta$-meATP, a potent agonist of the $\mathrm{P} 2 \mathrm{X}_{1} \mathrm{R}$, did not induce any $\left[\mathrm{Ca}^{2+}\right]_{\mathrm{i}}$ increase (not shown), suggesting that, although NK cells expressed detectable $\mathrm{P} 2 \mathrm{X}_{1} \mathrm{R}$ mRNA, no functional receptor was present on cell membrane.

We also tested the ATP analog BzATP, an agonist that preferentially, although not exclusively, activates the $\mathrm{P} 2 \mathrm{X}_{7} \mathrm{R}$ subtype. Figure 1D (solid line) shows that, similarly to ATP, 300 $\mathrm{M}$ BzATP induced a rapid $\left[\mathrm{Ca}^{2+}\right]_{\mathrm{i}}$ increase that remained sustained for several minutes. Because it is reported that BzATP is also active at the P2 $\mathrm{Y}_{11} \mathrm{R}$ subtype, we also performed stimulation of NK cells with this agonist in $\mathrm{Ca}^{2+}$-free conditions. Figure 1D (dashed line) shows that, when BzATP was applied in the absence of extracellular $\mathrm{Ca}^{2+}$, 
From www.bloodjournal.org at IRCCS ISTITUTO CLINICO HUMANITAS on November 29, 2010. For personal BLOOD, 25 NOVEMBER 2010 • VOLUME 116, NUMBER 22

Table 1. Checkerboard analysis of ATP-induced migration

\begin{tabular}{lcccc}
\hline $\begin{array}{l}\text { ATP, } \\
\boldsymbol{\mu M}\end{array}$ & $\begin{array}{c}\mathbf{0} \boldsymbol{\mu M} \\
\mathbf{A T P}\end{array}$ & $\begin{array}{c}\mathbf{0 . 1} \boldsymbol{\mu M} \\
\mathbf{A T P}\end{array}$ & $\begin{array}{c}\mathbf{1} \boldsymbol{\mu M} \\
\mathbf{A T P}\end{array}$ & $\begin{array}{c}\mathbf{1 0} \boldsymbol{\mu M} \\
\mathbf{A T P}\end{array}$ \\
\hline 0 & - & 1.1 & 2.2 & 6.1 \\
0.1 & 1.0 & 1.0 & 2.1 & 5.0 \\
1 & 7.7 & 1.5 & 2.2 & 5.3 \\
10 & 3.5 & 3.2 & 2.6 & 5.9 \\
\hline
\end{tabular}

Migration assay was performed as indicated in "Migration assays," adding ATP to the top and bottom chambers of the transwell (checkerboard analysis) as indicated. Data represent the migration index calculated as the ratio between the number of cells migrated in each condition and the number of cells migrated in the absence of ATP. Results are shown from 1 representative experiment of 3 performed.

- indicates not applicable.

no peak was detected. The BzATP dose-dependency curve is shown in Figure 1E. BzATP threshold concentration was approximately $30 \mu \mathrm{M}$, whereas $\Delta \mathrm{Ca}^{2+}$ at $300 \mu \mathrm{M}$ BzATP was 48.1 plus or minus 5.0nM. Different P2XR inhibitors are available; among them, oxidized ATP (oATP) and pyridoxalphosphate-6-azophenyl 2disulfonic acid (PPADS) are recognized as P2XR wide spectrum inhibitors, whereas $\mathrm{KN}-62$ is a $\mathrm{P} 2 \mathrm{X}_{7} \mathrm{R}$ noncovalent blocker. oATP, PPADS, and KN-62 completely abrogated the $\left[\mathrm{Ca}^{2+}\right]_{i}$ increase induced by BzATP in NK cells (Figure 1F).

As P2YR can be activated by different agonists depending on the subtype, we checked the response induced by 2MeSADP (an agonist at $\mathrm{P} 2 \mathrm{Y}_{1} \mathrm{R}$ ), which induced no $\mathrm{Ca}^{2+}$ increase or, in some subjects, a delayed/slowly increasing $\mathrm{Ca}^{2+}$ signal (not shown). ADP that activates $P 2 Y_{1} R, P 2 Y_{12} R$, and $P 2 Y_{13} R$ and UTP, which is an agonist at the $\mathrm{P} 2 \mathrm{Y}_{2} \mathrm{R}, \mathrm{P} 2 \mathrm{Y}_{4} \mathrm{R}$, and $\mathrm{P} 2 \mathrm{Y}_{6} \mathrm{R}$ subtypes, did not induce any appreciable $\mathrm{Ca}^{2+}$ increase, as well as UDP, which is very active at the $\mathrm{P} 2 \mathrm{Y}_{6} \mathrm{R}$ subtype and UDP-glucose (agonist at $\mathrm{P} 2 \mathrm{Y}_{14} \mathrm{R}$; not shown). The nonhydrolyzable ATP analog ATP- $\gamma \mathrm{S}$, which is an agonist at the $\mathrm{P} 2 \mathrm{Y}_{11} \mathrm{R}$ subtype, gave an appreciable $\mathrm{Ca}^{2+}$ signal only in some of the subjects tested (not shown). However, as the $\mathrm{P} 2 \mathrm{Y}_{11} \mathrm{R}$ has the unique (among $\mathrm{P} 2 \mathrm{Rs}$ ) ability to induce increased intracellular cAMP (cAMPi) concentration in addition to mobilizing intracellular calcium, the lack of intracellular $\mathrm{Ca}^{2+}$ mobilization on ATP- $\gamma \mathrm{S}$ stimulation is not sufficient to exclude $\mathrm{P} 2 \mathrm{Y}_{11} \mathrm{R}$ activation.

\section{ATP, but not UTP, influences NK cell motility and chemotaxis}

We asked whether extracellular nucleotides could affect migratory properties of NK cells. Neither ATP nor UTP was able to induce chemotaxis of NK cells in a concentration range spanning from $1 \mathrm{nM}$ to $100 \mu \mathrm{M}$ (data not shown), yet ATP (but not UTP) increased NK-cell nondirectional motility (chemokinesis) as shown by checkerboard analysis (Table 1). However, exposure to extracellular ATP (but not UTP) markedly modified NK-cell migratory response to chemokines. Ninety percent of circulating NK cells were $\mathrm{CD}_{16}{ }^{+}$and expressed $\mathrm{CX}_{3} \mathrm{CR} 1$ and CXCR4 chemokine receptors. In vitro chemotaxis assays showed dose-dependent NK-cell migration induced by $\mathrm{CX}_{3} \mathrm{CL} 1$. However, in the presence of $100 \mu \mathrm{M}$ ATP, $\mathrm{CX}_{3}$ CL1-induced chemotaxis was completely blocked (Figure 2A). Moreover, ATP-induced block of chemotaxis was dose-dependent, whereas UTP failed to alter NK-cell migration (Figure 2B). Flow cytometric analysis showed that ATP did not significantly alter $\mathrm{CX}_{3} \mathrm{CR} 1$ expression on NK-cell membrane (Figure $2 \mathrm{C}$ ). $\mathrm{CX}_{3} \mathrm{CR} 1$ mean fluorescence intensity remained relatively high, and the percentage of $\mathrm{CX}_{3} \mathrm{CR} 1^{+} \mathrm{NK}$ cells was unchanged and proximal to $100 \%$, thus indicating that ATP did not inhibit $\mathrm{CX}_{3} \mathrm{CL} 1$-mediated effects through $\mathrm{CX}_{3} \mathrm{CR} 1$ down-regulation. In contrast with the inhibition exerted by ATP on $\mathrm{CX}_{3} \mathrm{CL} 1-$ induced chemotaxis, NK cells migrated more vigorously to CXCL12 in the presence of ATP rather than in its absence (Figure 3A). This effect was not the result of acute CXCR4 up-regulation as shown in Figure 3B. Similarly, chronic (16 hours) stimulation with ATP enhanced responsiveness to CXCL12 of resting and IL-2-activated NK cells (Figure 3C). In such stimulation conditions, ATP alone did not alter CXCR4 expression (Figure 3D top panels); however, IL-2-induced receptor down-regulation was partially prevented by the presence of ATP (Figure 3D bottom panels), and this effect

A

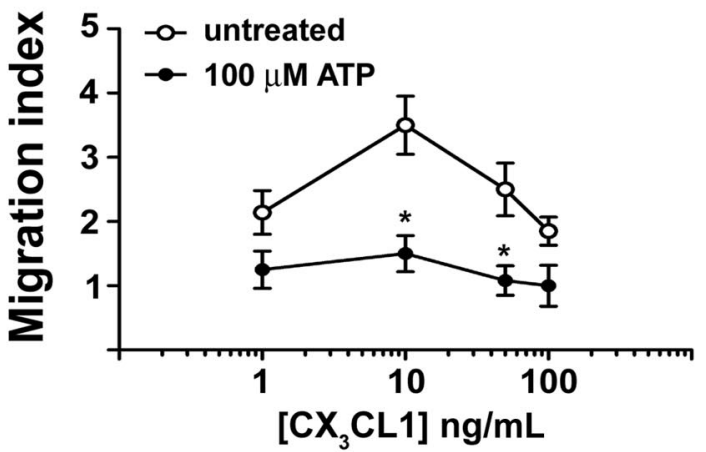

B

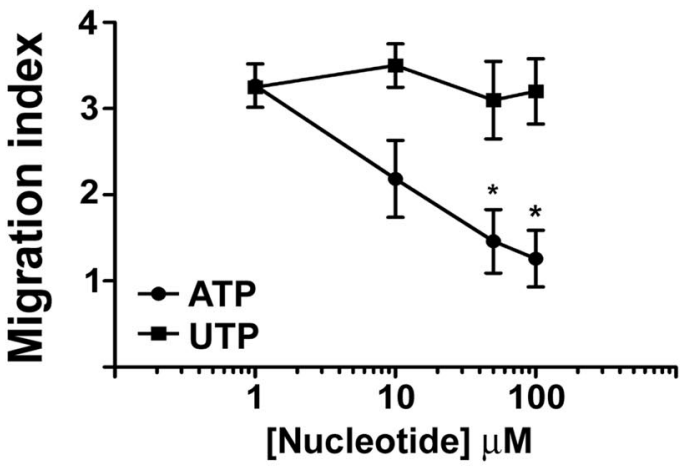

C

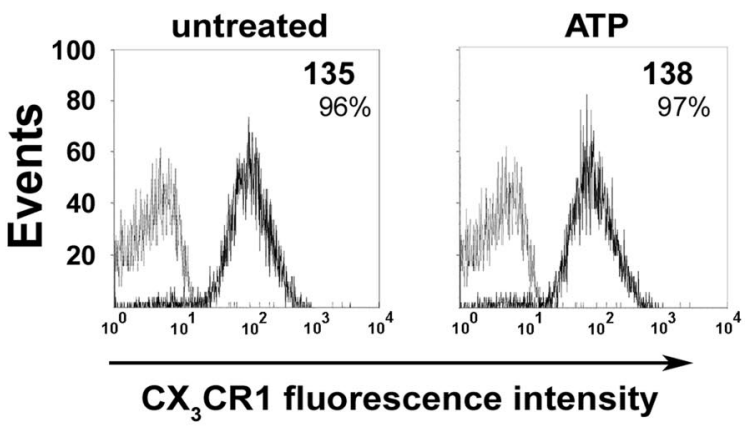

Figure 2. ATP inhibits chemotaxis of NK cells induced by $\mathrm{CX}_{3} \mathrm{CL1}$. (A) Migratory response of NK cells to $\mathrm{CX}_{3} \mathrm{CL} 1$ gradients in the presence $(\bullet)$ or absence $(\bigcirc)$ of $100 \mu \mathrm{M}$ ATP. ${ }^{*} P<.05$ versus cells stimulated with the same dose of $\mathrm{CX}_{3} \mathrm{CL} 1$ in the absence of ATP as assessed by Student $t$ test for paired samples. (B) Dose dependency of the inhibitory effect of ATP or UTP on the migration of NK cells to $\mathrm{CX}_{3} \mathrm{CL} 1$. NK lymphocytes migrated to $10 \mathrm{ng} / \mathrm{mL} \mathrm{CX}{ }_{3} \mathrm{CL} 1$ added to the bottom chamber along with the indicated concentrations of ATP $(\bullet)$ or UTP $(\square)$. ${ }^{*} P<.05$ versus cells stimulated with UTP assessed by Student $t$ test for paired samples. (C) Flow cytometric analysis of the expression of $\mathrm{CX}_{3} \mathrm{CR} 1$ on the membrane of $\mathrm{NK}$ cells left untreated or exposed to $100 \mu \mathrm{M}$ ATP for 60 minutes. Numbers represent the net mean fluorescence calculated subtracting the mean fluorescence obtained with isotype control $\mathrm{mAb}$ (gray line) to the fluorescence obtained with anti-CX ${ }_{3} \mathrm{CR} 1 \mathrm{mAb}$ (black line). (A-B) Data are mean \pm SD from 4 experiments. In all chemotaxis assays, each concentration used of $\mathrm{CX}_{3} \mathrm{CL} 1$ induced statistically significant increase of NK-cell chemotaxis compared with the unstimulated cells. $P<.05$ assessed by Student $t$ test for unpaired samples. (C) Representative results from 1 of 3 experiments. 

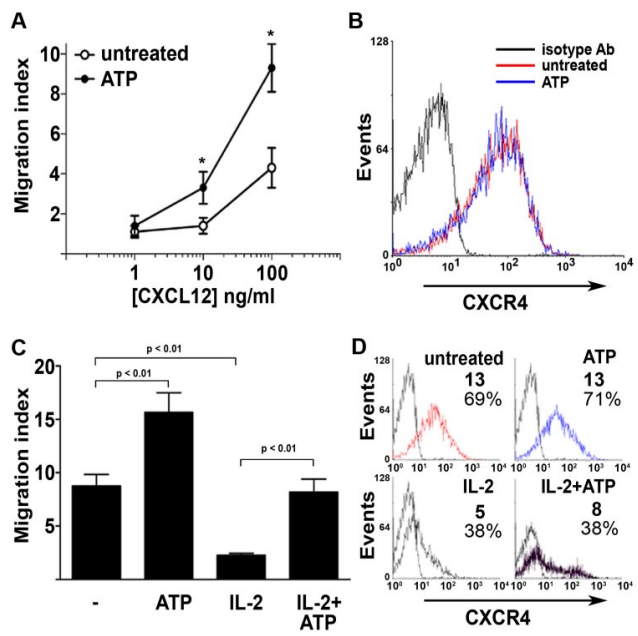

Figure 3. ATP enhances NK-cell chemotactic response to CXCL12. (A) Migratory response of NK cells to CXCL12 gradients in the presence $(\bullet)$ or absence $(\bigcirc)$ of $100 \mu \mathrm{M}$ ATP. ${ }^{*} P<.05$ versus cells stimulated with same $\mathrm{CXCL} 12$ dose in the presence of UTP. (B) Expression of CXCR4 on NK cells surface after 1-hour exposure to $100 \mu \mathrm{M}$ ATP. (C) Migratory response of NK cells to $100 \mathrm{ng} / \mathrm{mL}$ CXCL12 after 16-hour incubation with or without $1000 \mathrm{U} / \mathrm{mL} \mathrm{IL-2}$ in the presence or absence of $100 \mu \mathrm{M}$ ATP. (D) Expression of CXCR4 after 16-hour incubation with or without $1000 \mathrm{U} / \mathrm{mL}$ IL-2 in the presence or absence of $100 \mu$ M ATP. (D) Data are the mean fluorescence intensity and percentages of CXCR4 ${ }^{+}$cells. $(A, C)$ Data are the mean $\pm S D$ of 3 experiments. (B,D) Data are representative from 1 of 3 experiments. ${ }^{\star} P<.05$. All $P$ values were calculated by Student $t$ test for paired samples.

correlated to chemotactic response to CXCL12. Taken together, these data show that extracellular ATP exerts distinct regulatory effects on NK-cell chemotaxis in response to $\mathrm{CX}_{3} \mathrm{CL} 1$ or CXCL12. Moreover, ATP-dependent enhancement of chemokinesis and chemotaxis to CXCL12 indicates that ATP-induced reduction of NK-cell response to $\mathrm{CX}_{3} \mathrm{CL1}$ is not the result of a toxic effect. Intrinsic ATP toxicity was further excluded by flow cytometric analysis of NK cells stained with annexin $\mathrm{V}$ and propidium iodide for the detection of early apoptotic and late apoptotic or necrotic cells (supplemental Figure 2). Cell death was not detected at the ATP concentration used to stimulate NK cells $(100 \mu \mathrm{M})$ but only occurred at concentrations as high as $1 \mathrm{mM}$.

\section{Extracellular ATP blocks the ability of $\mathrm{CX}_{3} \mathrm{CL} 1$ to stimulate NK-cell cytotoxicity}

As ATP inhibited $\mathrm{CX}_{3} \mathrm{CL} 1$-induced NK-cell migration, we sought to determine whether ATP also affected $\mathrm{CX}_{3} \mathrm{CL} 1$ stimulation of NK-cell cytotoxicity. First, we evaluated the effect of the exposure to ATP on NK cell-mediated cytolysis of the monocytic cell line K562, a classic cellular target for in vitro NK cytotoxicity studies. In keeping with previous observations, soluble $\mathrm{CX}_{3} \mathrm{CL} 1$ increased NK cell-mediated killing of K562 target cells ${ }^{9}$ (Figure 4A). However, in the presence of $100 \mu \mathrm{M}$ ATP, $\mathrm{CX}_{3} \mathrm{CL} 1$ failed to enhance NK-cell cytolytic activity. Similarly to what was observed for chemotaxis, $\mathrm{CX}_{3} \mathrm{CL} 1$ concentrations as low as $1 \mathrm{ng} / \mathrm{mL}$ significantly enhanced NK-cell cytotoxicity; however, maximal stimulation was obtained using $10 \mathrm{ng} / \mathrm{mL} \mathrm{CX}_{3} \mathrm{CL} 1$, and we therefore used such dose hereinafter in all experiments.

Next, we asked whether the block of $\mathrm{CX}_{3} \mathrm{CL} 1$-dependent increase of NK-cell cytotoxicity was reproducible using ECs as target cells (Figure 4B). ATP alone did not significantly alter basal NK-cell killing activity (not shown). However, in the presence of ATP, or of the nonhydrolyzable ATP analog ATP- $\gamma \mathrm{S}, \mathrm{CX}_{3} \mathrm{CL} 1$ failed to stimulate killing of HUVECs. Pretreatment with NF157, a compound that selectively blocks the $\mathrm{P} 2 \mathrm{Y}_{11} \mathrm{R}$ and the $\mathrm{P} 2 \mathrm{X}_{1} \mathrm{R}$, restored $\mathrm{CX}_{3} \mathrm{CL} 1$ ability to stimulate cytolysis of HUVECs in NK cells exposed to ATP or ATP- $\gamma \mathrm{S}$. This finding suggests that ATP-dependent block of $\mathrm{CX}_{3} \mathrm{CL} 1$ stimulatory effects was mediated by $\mathrm{P} 2 \mathrm{X}_{1} \mathrm{R}$ and/or $\mathrm{P} 2 \mathrm{Y}_{11} \mathrm{R}$.

Stimulation of HUVECs with TNF- $\alpha$ enhances surface expression of $\mathrm{CX}_{3} \mathrm{CL} 1$ as well as expression of enzymes mediating $\mathrm{CX}_{3} \mathrm{CL} 1$ cleavage and shedding. ${ }^{16-18}$ Therefore, we compared the susceptibility of TNF- $\alpha$-activated HUVECs with NK-cell cytolysis in the presence or absence of ATP. HUVECs are relatively resistant to NK cell-mediated cytolysis, and significant cytolytic activity is measurable at higher effector/target ratios compared with those needed for K562 cells. Activated HUVECs displayed increased susceptibility to NK cell-dependent cytolysis that was already detectable at an effector/target ratio as low as 20:1. Lysis of untreated HUVECs was undetectable at this level. However, cytotoxicity toward TNF- $\alpha$-activated HUVECs by NK cells preexposed to ATP was superimposable with that of NK cells toward unstimulated HUVECs (Figure 4C).

We also performed cytotoxicity assays using HCAECs, a second EC line as a target for NK cell-mediated cytotoxicity. ATP and ATP- $\gamma \mathrm{S}$ also inhibited the ability of $\mathrm{CX}_{3} \mathrm{CL} 1$ to stimulate NK-cell killing of HCAECs, confirming the results obtained with HUVECs (Figure 4D). Moreover, the killing of HCAECs by NK cells exposed to ATP or ATP- $\gamma \mathrm{S}$ was restored by NF157, again indicating the involvement of the $\mathrm{P} 2 \mathrm{Y}_{11} \mathrm{R}$ and/or $\mathrm{P} 2 \mathrm{X}_{1} \mathrm{R}$ as mediators of ATP-dependent NK-cell function inhibition.

As ECs can secrete discrete amounts of ATP in the extracellular space, we sought to determine whether such secretion was able to affect NK cell-mediated killing of ECs. Therefore, we performed cytotoxicity assays coculturing NK cells and HUVECs in the presence or absence of the ATP-hydrolyzing enzyme apyrase. The addition of apyrase to HUVEC culture 1 hour before or at time of the addition of NK cells dramatically enhanced the lysis of ECs (Figure 4E).

\section{Inhibition of NK-cell response to $\mathrm{CX}_{3} \mathrm{CL1}$ is mediated by the $\mathrm{P}_{2} \mathrm{Y}_{11}$ receptor}

As NF157 can inhibit both $\mathrm{P} 2 \mathrm{Y}_{11} \mathrm{R}$ and $\mathrm{P} 2 \mathrm{X}_{1} \mathrm{R}$, we next conducted a series of experiments to assess whether both receptors are involved in mediating ATP-dependent inhibitory effects. We then studied ATP inhibition of NK chemotaxis to $\mathrm{CX}_{3} \mathrm{CL} 1$ in the presence of NF157, or MRS2159 and NF023, 2 different $\mathrm{P}_{2} \mathrm{X}_{1}$ inhibitors. ${ }^{19-22}$ Although NF157 restored NK chemotaxis abolished by ATP, neither MRS2159 nor NF023 modified NK-cell migration to $\mathrm{CX}_{3} \mathrm{CL} 1$ in the presence of ATP (Figure 5A). Similarly, NK-cell killing of HUVECs that was elicited by $\mathrm{CX}_{3} \mathrm{CL} 1$ and blocked by ATP was restored by NF157 but not by $\mathrm{P}_{2} \mathrm{X}_{1}$ antagonists (Figure 5B). In addition, the medium used to culture NK cells (RPMI 1640) contained $13.3 \mu \mathrm{M}$ phenol red, a concentration 4.3-fold higher than the reported 50\% inhibitory concentration for $\mathrm{P} 2 \mathrm{X}_{1} \cdot{ }^{23}$ Therefore, we assessed whether phenol red might have modified ATP effect on NK cells repeating chemotaxis and cytotoxicity assays in a phenol red-free medium. Results shown in Figure 5C-D indicate that phenol red did not affect ATP capacity to block migration or cytotoxicity of NK cells in response to $\mathrm{CX}_{3}$ CL1. In keeping with the lack of functional $\mathrm{P} 2 \mathrm{X}_{1} \mathrm{R}, \alpha, \beta$-meATP, an agonist at the $\mathrm{P} 2 \mathrm{X}_{1} \mathrm{R}$ but not at the $\mathrm{P} 2 \mathrm{Y}_{11} \mathrm{R}$, did not modify chemotaxis or cytotoxicity of $\mathrm{NK}$ cells in response to $\mathrm{CX}_{3} \mathrm{CL} 1$ (data not shown). Taken together, these results suggested that $\mathrm{P} 2 \mathrm{Y}_{11} \mathrm{R}$, but not $\mathrm{P} 2 \mathrm{X}_{1} \mathrm{R}$, mediated the inhibition of NK-cell responsiveness to $\mathrm{CX}_{3} \mathrm{CL} 1$ exerted by ATP. 
A

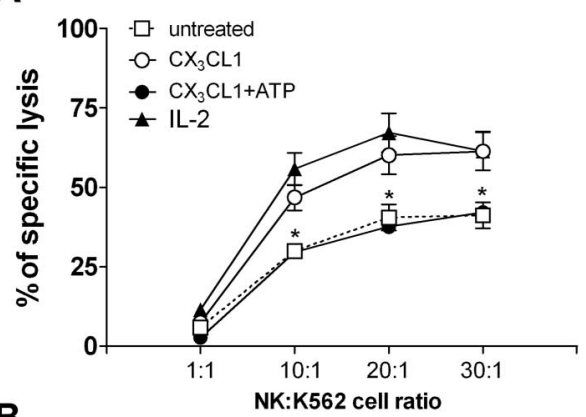

B

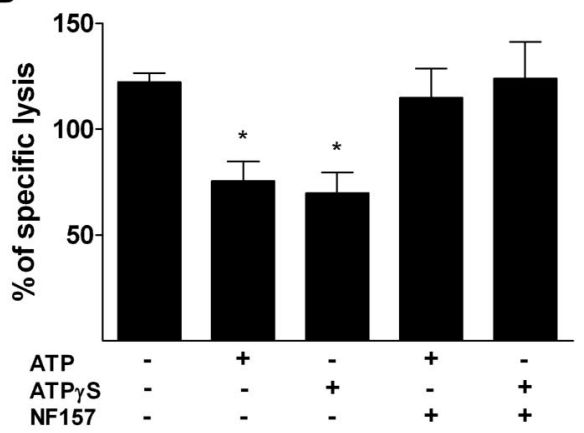

C

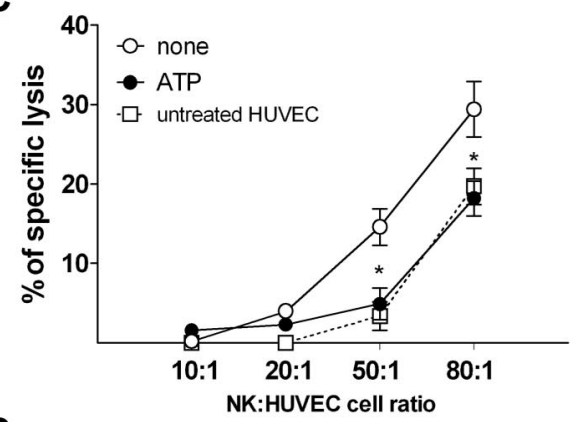

D
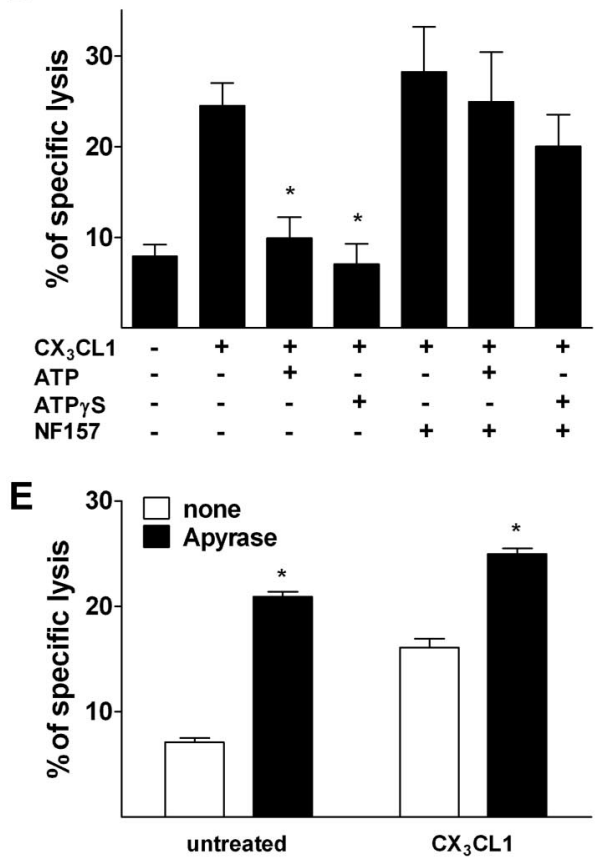

A

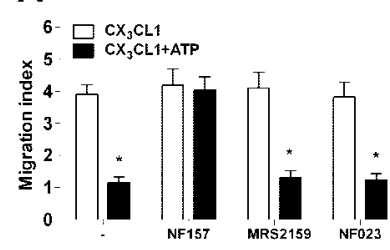

C

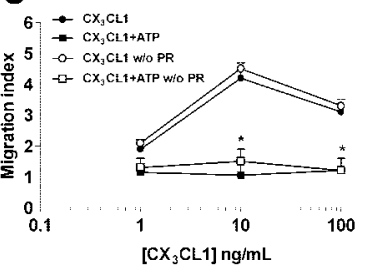

Figure 5. NF157, but not P2X ${ }_{1}$, specific antagonists MRS2159 and NF023 restore NK responsiveness to $\mathrm{CX}_{3} \mathrm{CL} 1$. (A) NK-cell chemotaxis to $10 \mathrm{ng} / \mathrm{mL}$ $\mathrm{CX}_{3} \mathrm{CL} 1$ in the presence or absence of $100 \mu \mathrm{M}$ ATP with or without 30-minute pretreatment with $100 \mu \mathrm{M}$ NF157, $10 \mu \mathrm{M}$ MRS2159, or $1 \mu \mathrm{M}$ NF023. ${ }^{*} P<.05$, $\mathrm{CX}_{3} \mathrm{CL} 1$ versus $\mathrm{CX}_{3} \mathrm{CL} 1+\mathrm{ATP}$. (B) NK-cell killing of HUVECs after stimulation with or without $10 \mathrm{ng} / \mathrm{mL} \mathrm{CX}{ }_{3} \mathrm{CL} 1$ in the presence or absence of ATP and the indicated inhibitors. ${ }^{*} P<.05, \mathrm{CX}_{3} \mathrm{CL} 1$ versus $\mathrm{CX}_{3} \mathrm{CL} 1+$ ATP. (C) Chemotaxis of NK cells to $\mathrm{CX}_{3} \mathrm{CL} 1$ with or without ATP and in the presence or absence of phenol red. ${ }^{*} P<.05$, $\mathrm{CX}_{3} \mathrm{CL} 1$ versus $\mathrm{CX}_{3} \mathrm{CL} 1+$ ATP. (D) NK-cell killing of HUVECs stimulated or not with $\mathrm{CX}_{3} \mathrm{CL} 1$ with or without ATP and the presence or absence of phenol red. ${ }^{*} P<.05$, $\mathrm{CX}_{3} \mathrm{CL} 1$ versus $\mathrm{CX}_{3} \mathrm{CL} 1+\mathrm{ATP}$.

\section{ATP inhibits NK-cell responsiveness to $\mathrm{CX}_{3} \mathrm{CL1}$ via increased amount of intracellular cAMP}

In the attempt to identify the receptor mediating the inhibitory effects of ATP, we assessed whether $\mathrm{NAD}^{+}$, another physiologic agonist at the $\mathrm{P} 2 \mathrm{Y}_{11}$ receptor, ${ }^{24}$ was able to mimic ATP in blocking $\mathrm{NK}$ chemotaxis toward $\mathrm{CX}_{3} \mathrm{CL} 1$. $\mathrm{NAD}^{+}$dose-dependently inhibited NK-cell chemotaxis to $\mathrm{CX}_{3} \mathrm{CL} 1$; however, when NK cells were preincubated with NF157 but not with MRS2159 or NF023, NAD ${ }^{+}$ was unable to block NK-cell migration (Figure 6A). Because the $\mathrm{P} 2 \mathrm{Y}_{11} \mathrm{R}$ is the only $\mathrm{P} 2 \mathrm{R}$ linked to adenylate cyclases activation, we assessed whether ATP or $\mathrm{NAD}^{+}$was able to increase intracellular cAMPi concentration in NK cells. After a 15-minute incubation with either ATP or $\mathrm{NAD}^{+}$, NK cells displayed dramatically increased cAMPi levels. Such an effect was abolished by preincubation with NF157 but not MRS2159 or NF023 (Figure 6B). We next asked whether NK chemotaxis to $\mathrm{CX}_{3} \mathrm{CL} 1$ was inhibited by increased cAMPi concentration. Therefore, cells were incubated with the cell-permeable cAMP analog 8Br-cAMP before the stimulation with $\mathrm{CX}_{3} \mathrm{CL} 1$. Increasing doses of $8 \mathrm{Br}$-cAMP inhibited NK-cell chemotaxis to $\mathrm{CX}_{3} \mathrm{CL} 1$, and coincubation with NF157 was unable to restore cell migration (Figure 6C). Similarly, NF157

Figure 4. ATP inhibits $\mathrm{CX}_{3} \mathrm{CL1}$-induced NK-cell cytotoxicity. (A) Effect of $100 \mu \mathrm{M}$ ATP on $10 \mathrm{ng} / \mathrm{mL} \mathrm{CX}_{3} \mathrm{CL} 1$-induced NK cell-mediated killing of $\mathrm{K} 562$ cells ${ }^{\star} P<.05$, $\mathrm{CX}_{3} \mathrm{CL} 1$ versus $\mathrm{CX}_{3} \mathrm{CL} 1+\mathrm{ATP}$. (B) $\mathrm{CX}_{3} \mathrm{CL} 1$ ability to increase HUVEC killing by NK cells is blocked by ATP and ATP- $\gamma$ S and restored by NF157. NK cells were treated with $10 \mathrm{ng} / \mathrm{mL} \mathrm{CX}{ }_{3} \mathrm{CL} 1$ in the presence of the indicated stimuli $(100 \mu \mathrm{M}$ ATP, $10 \mu \mathrm{M}$ ATP- $\gamma \mathrm{S}, 100 \mu \mathrm{M} N \mathrm{NF} 157)$ for 2 hours before the coculture performed at $80: 1$ (NK/target cells) ratio. ${ }^{\star} P<.05$ versus cells treated with $\mathrm{CX}_{3} \mathrm{CL} 1$ only. (C) ATP $(100 \mu \mathrm{M})$ inhibits NK cell-mediated cytolytic activity against TNF- $\alpha$-activated ECs. HUVECs were left untreated or stimulated for 16 hours with $50 \mathrm{ng} / \mathrm{mL} \mathrm{rhTNF}-\alpha$ and used in cytotoxicity assay. ${ }^{\star} P<.05$ versus cells treated with TNF- $\alpha$ only. (D) Effect of $100 \mu \mathrm{M}$ ATP and $10 \mu \mathrm{M}$ ATP- $\gamma \mathrm{S}$ on $\mathrm{CX}_{3} \mathrm{CL} 1$-induced killing of HCAECs by NK cells. ${ }^{*} P<.05$ versus cells treated with $\mathrm{CX}_{3} \mathrm{CL} 1$ only. $(\mathrm{E})$ Hydrolysis of endogenous extracellular ATP by apyrase $(1 \mathrm{U} / \mathrm{mL})$ enhances basal and $\mathrm{CX}_{3} \mathrm{CL} 1$-induced NK cellmediated killing of HUVECs. ${ }^{*} P<.05$. Data are mean \pm SD of percentages of unstimulated NK cells from 3 independent experiments. All $P$ values were calculated by Student $t$ test for paired samples. 
A

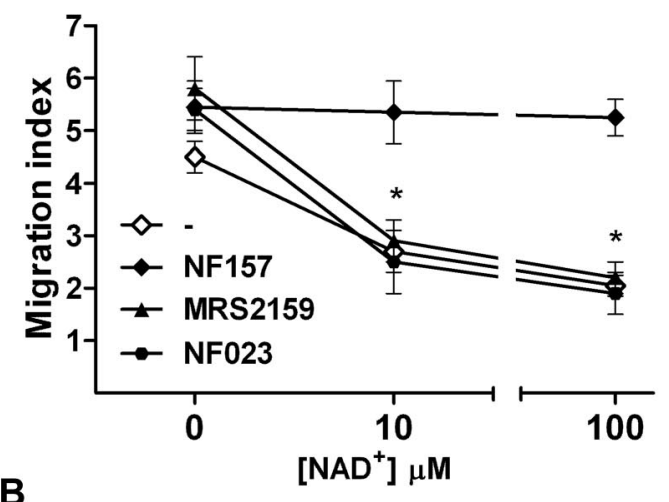

B

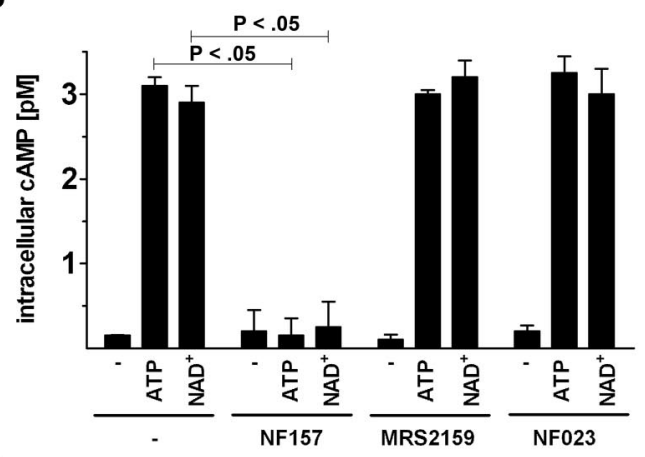

C
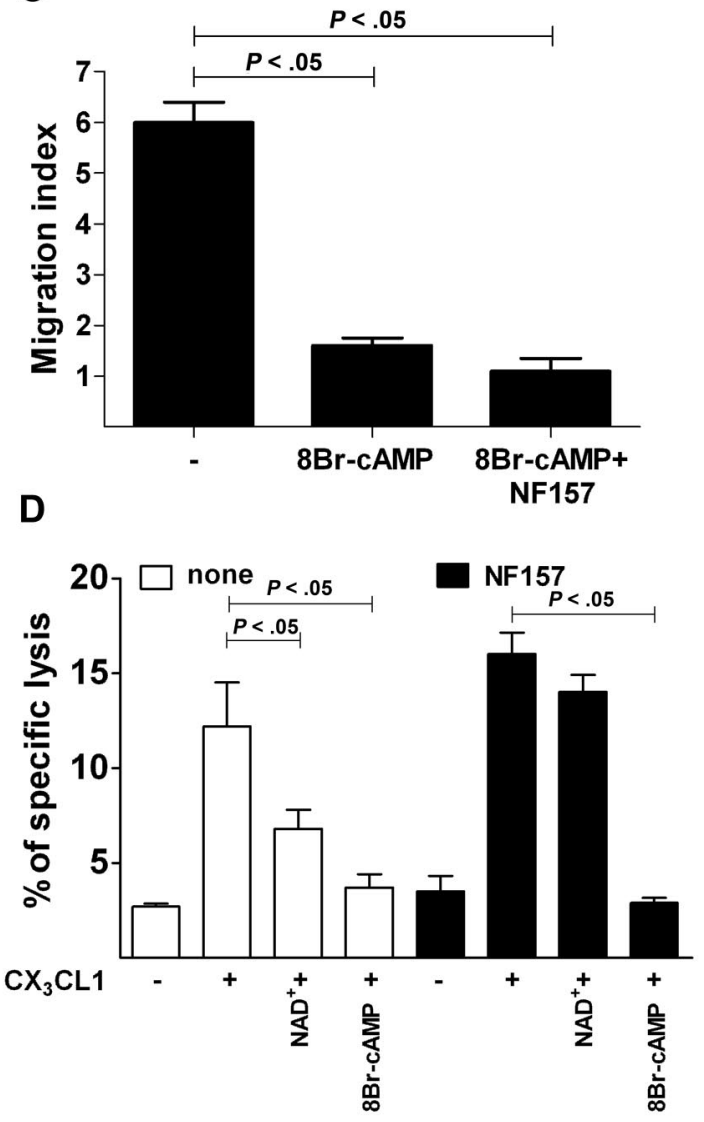

restored $\mathrm{CX}_{3} \mathrm{CL} 1$-stimulated killing of HUVEC cell line by NK cells exposed to $\mathrm{NAD}^{+}$but not to $8 \mathrm{Br}$-cAMP (Figure 6D), indicating that $\mathrm{P}_{2} \mathrm{Y}_{11} \mathrm{R}$ activation negatively regulates $\mathrm{CX}_{3} \mathrm{CR} 1$ signaling, possibly by increasing cAMPi.

\section{Discussion}

In this study, we showed that NK cells express a wide array of P2Rs of both P2XR and P2YR subgroups. Pharmacologic analysis showed that extracellular nucleotides activated a $\mathrm{Ca}^{2+}$ signal in NK cells. Although unable to exert direct chemotactic effect on NK cells, ATP induced a marked increase of chemokinesis and displayed opposite regulatory effect on NK-cell chemotactic responses to $\mathrm{CX}_{3} \mathrm{CL} 1$ and CXCL12 (ie, a potent inhibitory effect on $\mathrm{CX}_{3} \mathrm{CL} 1$-induced NK-cell migration was exerted by ATP and by its nonhydrolyzable analog ATP- $\gamma \mathrm{S}$ but not UTP). On the contrary, stimulation with ATP enhanced NK-cell migration to the lymphoid chemokine CXCL12. In addition, exposure to micromolar concentrations of ATP below the threshold required for P2XR activation significantly impaired the ability of $\mathrm{CX}_{3} \mathrm{CL} 1$ to stimulate cytotoxicity against ECs.

$\mathrm{CX}_{3} \mathrm{CL} 1$ plays a central role in NK-EC cross-talk: soluble $\mathrm{CX}_{3} \mathrm{CL} 1$ is released by activated ECs early during inflammation, recruiting leukocytes bearing its cognate receptor $\mathrm{CX}_{3} \mathrm{CR} 1$. In addition, $\mathrm{CX}_{3} \mathrm{CL} 1$ elicits interferon- $\gamma$ production by NK cells that, in turn, reinforces $\mathrm{CX}_{3} \mathrm{CL} 1$ expression by ECs. ${ }^{25}$ Moreover, activated ECs express membrane-bound form of $\mathrm{CX}_{3} \mathrm{CL} 1$ that functions as an adhesion molecule reinforcing cell-cell interaction. Of note, relatively high concentrations of $\mathrm{CX}_{3} \mathrm{CL} 1$ are probably present locally in the microenvironment of the NK-EC synapsis where activated endothelial cells produce both soluble and membrane-anchored forms of $\mathrm{CX}_{3} \mathrm{CL} 1$.

Because of reiterated interaction with extravasating activated leukocytes, ECs are particularly exposed to the risk of cumulating incidental cell damage, especially in the context of excessive inflammation. Although NK/endothelial cell ratios used for in vitro citotoxicity assays might not be exactly reproduced in vivo, smaller $\mathrm{NK} / \mathrm{EC}$ ratios likely to occur in vivo might be sustained for an amount of time significantly greater than the duration of the in vitro experiment. As a consequence, ECs might cumulate cell injury over time because of the sequential contact with a large number of potentially harmful activated NK cells.

ECs represent a major source of actively secreted ATP, ${ }^{26}$ pointing it out as an important player in the regulation of NK-EC interaction. In keeping with previous observations, we showed that

Figure 6. $P 2 Y_{11} R$ activation increases $c A M P i$ and mediates ATP-induced inhibition of $\mathrm{CX}_{3} \mathrm{CL1}$-elicited chemotaxis and cytotoxicity of NK cells. (A) Effect of $\mathrm{NAD}^{+}$on $\mathrm{CX}_{3} \mathrm{CL}$ 1-induced NK-cell chemotaxis. Cells were preincubated with or without the indicated inhibitors, stimulated with $10 \mathrm{ng} / \mathrm{mL} \mathrm{CX}{ }_{3} \mathrm{CL} 1$ alone in the presence of the indicated concentrations of $\mathrm{NAD}^{+}$for 60 minutes and cell migration measured as indicated in "Migration assays." * $P<.05$, MRS2159 or NF023 versus NF157. (B) Induction of cAMPi by ATP and NAD ${ }^{+}$. NK cells were incubated at $37^{\circ} \mathrm{C}$ for 15 minutes with $100 \mu \mathrm{M}$ ATP or NAD ${ }^{+}$in the presence or absence of the indicated inhibitors, and concentration of cAMPi was measured as described in "Intracellular cAMP quantification." (C) Inhibition of $\mathrm{CX}_{3} \mathrm{CL} 1$-dependent NK-cell migration by $8 \mathrm{Br}$-cAMP. Chemotaxis was stimulated by $10 \mathrm{ng} / \mathrm{mL} \mathrm{CX}_{3} \mathrm{CL} 1$ alone or in the presence of $100 \mu \mathrm{M} 8 \mathrm{Br}$-cAMP in NK cells pretreated or not for 1 hour with $100 \mu \mathrm{M} \mathrm{NF157.}$ (D) $\mathrm{NAD}^{+}$and $8 \mathrm{Br}$-cAMP inhibit $\mathrm{CX}_{3} \mathrm{CL} 1$-elicited NK cytotoxicity against HUVECs. Cells were preincubated with (filled bars) or without (open bars) $100 \mu \mathrm{M} \mathrm{NF157} \mathrm{and}$ stimulated with $10 \mathrm{ng} / \mathrm{mL} \mathrm{CX}_{3} \mathrm{CL} 1$ alone in the presence of $100 \mu \mathrm{M} \mathrm{NAD}^{+}$or $100 \mu \mathrm{M}$ $8 \mathrm{Br}$-cAMP and used for cytotoxicity assay against K562 cells. (A-C) Data are mean \pm SD of triplicate cultures from 3 independent experiments. (D) Data are mean \pm SD of sextuplicate cultures from 3 independent experiments. All $P$ values were calculated performing Student $t$ test for paired samples. 
$\mathrm{CX}_{3} \mathrm{CL} 1$ can significantly increase cytolytic activity of NK cells toward ECs. ${ }^{9}$ However, in the presence of ATP, $\mathrm{CX}_{3} \mathrm{CL} 1$ failed to enhance NK cell-mediated cytolysis of target cells. Similar inhibitory effect was displayed by $\mathrm{NAD}^{+}$and $\mathrm{ATP}-\gamma \mathrm{S}$ at 10 -fold lower concentration (maximal inhibitory effect of ATP- $\gamma \mathrm{S}$ was $10 \mu \mathrm{M}$ vs $100 \mu \mathrm{M}$ for ATP). On the other hand, ATP-dependent inhibition of NK-cell cytotoxicity was not altered by treatment with adenosine deaminase (data not shown), excluding a possible participation of adenosine, as end-product of ATP metabolism, potentially affecting NK cells through the engagement of adenosine receptors. Ruling out ATP metabolites as possible mediators of NK-cell killing inhibition is particularly important because both endothelial and activated NK cells express ectoapyrase (CD39), a membrane ATP diphosphohydrolase that hydrolyzes ATP and ADP into AMP. ${ }^{27,28}$

NF157, a compound known to inhibit $\mathrm{P} 2 \mathrm{Y}_{11} \mathrm{R}$ and $\mathrm{P} 2 \mathrm{X}_{1} \mathrm{R}$, restored NK-cell responsiveness to $\mathrm{CX}_{3} \mathrm{CL} 1$ both in terms of chemotaxis and cytolytic activity. A number of observations, however, ruled out the possible involvement the $\mathrm{P} 2 \mathrm{X}_{1}$ receptor in mediating ATP inhibitory effect: (1) although activation of the P2X receptors required greater than $300 \mu \mathrm{M}$ ATP concentrations, the block of $\mathrm{CX}_{3} \mathrm{CL} 1$ responsiveness occurred at $100 \mu \mathrm{M}$ ATP; (2) $\alpha, \beta$-meATP, a potent $P 2 X_{1} R$ agonist, did not elicit $\left[\mathrm{Ca}^{2+}\right]_{i}$ increase, or inhibit the ability of $\mathrm{CX}_{3} \mathrm{CL} 1$ to stimulate $\mathrm{NK}$ chemotaxis and cytotoxicity; (3) 3 different $\mathrm{P} 2 \mathrm{X}_{1} \mathrm{R}$ antagonists, such as MRS2159, NF023, and phenol red, failed to restore NK-cell responsiveness to $\mathrm{CX}_{3} \mathrm{CL} 1$. On the other hand, we provided evidence pointing out the $\mathrm{P} 2 \mathrm{Y}_{11} \mathrm{R}$ as key mediator of the inhibitory action exerted by ATP: the inhibition of $\mathrm{CX}_{3} \mathrm{CL} 1$ capacity to stimulate $\mathrm{NK}$ cell was mimicked by $\mathrm{NAD}^{+}$, another physiologic $\mathrm{P} 2 \mathrm{Y}_{11} \mathrm{R}$ ligand (which is not known to engage $\mathrm{P} 2 \mathrm{X}_{1} \mathrm{R}$ ) and by the ATP analog ATP- $\gamma \mathrm{S}$, which is a better agonist than ATP at the $\mathrm{P} 2 \mathrm{Y}_{11} \mathrm{R}$; both ATP and $\mathrm{NAD}^{+}$induced markedly increased cAMPi in NK cells, and among P2Rs, $\mathrm{P} 2 \mathrm{Y}_{11} \mathrm{R}$ is the only member known to stimulate adenylyl cyclases, thus increasing cAMPi concentration ${ }^{29}$; ATP and $\mathrm{NAD}^{+}$failed to increase cAMPi in the presence of NF157 but not P2X $\mathrm{X}_{1} \mathrm{R}$ inhibitors; NK cells exposed to the cell-permeable cAMP analog 8Br-cAMP displayed loss of sensitivity to $\mathrm{CX}_{3} \mathrm{CL} 1$ similar to that observed after stimulation with ATP or NAD ${ }^{+}$; and NF157 failed to restore NK-cell responses to $\mathrm{CX}_{3} \mathrm{CL} 1$ inhibited by $8 \mathrm{Br}$-cAMP. This observation suggests that NK-cell loss of responsiveness to $\mathrm{CX}_{3} \mathrm{CL} 1$ is secondary to cAMPi elevation, an event downstream to the engagement of $\mathrm{P} 2 \mathrm{Y}_{11} \mathrm{R}$ by its cognate ligands.

Similarly to what was previously observed in dendritic cells, no intracellular $\mathrm{Ca}^{2+}$ mobilization was induced by BzATP a preferential agonist for $\mathrm{P} 2 \mathrm{Y}_{11} \mathrm{R}$, or by $\mathrm{ATP}-\gamma \mathrm{S}$ despite the expression of discrete amount of the specific mRNA, ${ }^{30}$ suggesting that in NK and dendritic cells $\mathrm{P} 2 \mathrm{Y}_{11} \mathrm{R}$ signals almost exclusively through cAMPi as second messenger.

A limitation of this study is the technical impossibility in this setting to demonstrate the role of $\mathrm{P} 2 \mathrm{Y}_{11} \mathrm{R}$ by a more direct approach, such as receptor gene knockdown. Indeed, in vitro NK-cell viability depends on the presence of IL-2. After stimulation with IL-2, NK cells lost chemotactic response to $\mathrm{CX}_{3} \mathrm{CL} 1$, making it impossible to assess the effect ATP on chemotaxis. On the other hand, IL-2 strongly stimulated NK-cell cytolytic activity, thus masking any stimulatory effect of $\mathrm{CX}_{3} \mathrm{CL} 1$ (data not shown).

The activation of the $\mathrm{P} 2 \mathrm{Y}_{11} \mathrm{R}$ by ATP has been shown to alter the functions of other leukocyte subsets: $\mathrm{P} 2 \mathrm{Y}_{11} \mathrm{R}$ activation mediated the ATP-dependent inhibition of TNF- $\alpha$ production in human peripheral blood. ${ }^{31}$ In addition, $\mathrm{P} 2 \mathrm{Y}_{11} \mathrm{R}$ modulates the maturation of dendritic cells inhibiting TNF- $\alpha$ production ${ }^{32,33}$ and their ability to migrate in response to the lymphoid chemokine CCL21. ${ }^{30}$ Furthermore, $\mathrm{P} 2 \mathrm{Y}_{11} \mathrm{R}$ activation inhibits apoptosis in neutrophils. ${ }^{34}$

Some pathologic conditions associated with vascular injury can be, at least in part, mediated by NK cells. Heterologous ECs can be targeted by NK-cell cytotoxicity in allograft rejection or graft-versus-host disease. In addition, autologous ECs can become susceptible to NK cellmediated killing when infected by cytomegalovirus or in subjects with VLS associated with antitumoral therapy based on the administration of IL-2 or IL-2-activated cells. Interestingly, a key role for $\mathrm{CX}_{3} \mathrm{CL} 1$ in the stimulation of NK cell-mediated vascular injury in VLS has been proposed. ${ }^{9}$ The observed inhibitory effects exerted by ATP on NK cellmediated killing of ECs, together with the fact that ECs are able to actively secrete discrete amounts of ATP, ${ }^{26}$ suggest a potential role for ATP as a physiologic suppressor of incidental cytotoxicity exerted by excessively activated NK cells against ECs. Although the ATP concentration needed to affect NK-cell function in vitro is in the micromolar range, it has to be considered that even very small amounts of ATP secreted by ECs can cause a steep rise of ATP concentration in the microenvironment of the NK-EC synapse. In addition, $\mathrm{P} 2 \mathrm{Y}_{11} \mathrm{R}$ can be also be engaged by non-nucleotide agonists, such as $\mathrm{NAD}^{+24}$ and $\mathrm{NAADP}^{+}, 35$ which might cooperate in vivo with ATP and activate $\mathrm{P} 2 \mathrm{Y}_{11} \mathrm{R}$ at significantly lower concentrations than those needed in vitro. Moreover, the enhanced NK cell-mediated killing of ECs occurring in the presence of apyrase indicates that the amount of ATP spontaneously released by ECs is sufficient to significantly down-regulate NK cytotoxicity and that the inhibition of killing is not caused by increased extracellular concentration of ATP catabolites, such as adenosine, consistent with what observed by the exogenous addition of the nonhydrolyzable ATP analog ATP- $\gamma \mathrm{S}$ and adenosine deaminase.

Noteworthy, as no $\mathrm{P} 2 \mathrm{Y}_{11} \mathrm{R}$ homolog has been identified in rodents, it is at present unfeasible to study its role on the regulation of NK-ECs cross-talk in vivo.

In conclusion, ECs by secreting ATP, dampen NK-cell cytotoxicity, possibly preventing accidental vascular injury during extravasation of activated NK cells. In addition, our results indicate the $\mathrm{P} 2 \mathrm{Y}_{11} \mathrm{R}$ as essential mediator of the regulatory effect of ATP on NK-ECs cross-talk. Taken together, our data suggest that selective $\mathrm{P} 2 \mathrm{Y}_{11} \mathrm{R}$ agonists might be useful in limiting NK cell-mediated vascular injury occurring in various pathologic conditions, such as VLS, allograft rejection, and cytomegalovirus infection.

\section{Acknowledgments}

The authors thank Prof M. E. Mendelsohn for critical review of the manuscript and helpful suggestions.

This work was supported in part by Ricerca Finalizzata Ministero della Salute 2006 Terapia fisica da sola o combinata a terapie specifiche nel trattamento delle cardiovasculopatie, Regione Emilia-Romagna (Progetti di Ricerca Università-Regione Emilia Romagna, Progetto Medicina Rigenerativa, 2007), MIUR (PRIN 2006), the National Research Council of Italy, the Italian Association for Cancer Research, the Italian Space Agency, Telethon of Italy, and the University of Ferrara (local funds).

This paper is dedicated to the memory of Dr Giovanni Gorini.

\section{Authorship}

Contribution: S. Gorini and G.C. performed the experiments, analyzed the results, made the figures, and wrote the paper; G. 


\section{From www.bloodjournal.org at IRCCS ISTITUTO CLINICO HUMANITAS on November 29, 2010. For personal

Romagnoli, C.M., D.M., G. Rosano, M.F., S. Gulinelli, S.F., and A.C. performed part of the experiments; and F.D.V., D.F., and A.1.S. designed the research.

Conflict-of-interest disclosure: F.D.V. serves as a consultant for Cordex Pharma Inc and Affectis Pharmaceuticals AG (Germany), companies involved in the development of $\mathrm{P} 2$ receptor-based drugs. The remaining authors declare no competing financial interests.

Correspondence: Andrea la Sala, Laboratory of Molecular and Cellular Immunology, IRCCS San Raffaele Pisana, Via dei Bonacolsi, snc 00163 Rome, Italy; e-mail: andrea.lasala@ sanraffaele.it.

\section{References}

1. Di Virgilio F, Chiozzi P, Ferrari D, et al. Nucleotide receptors: an emerging family of regulatory molecules in blood cells. Blood. 2001;97(3):587-600.

2. Ostrom RS, Gregorian C, Insel PA. Cellular release of and response to ATP as key determinants of the set-point of signal transduction pathways. J Biol Chem. 2000;275(16):11735-11739.

3. Abbracchio M, Burnstock G. Purinoceptors: are there families of $\mathrm{P} 2 \mathrm{X}$ and $\mathrm{P} 2 \mathrm{Y}$ purinoceptors? Pharmacol Ther. 1994;64(3):445-475.

4. Dubyak GR, el Moatassim C. Signal transduction via P2-purinergic receptors for extracellular ATP and other nucleotides. Am J Physiol Cell Physiol. 1993;265(3):C577-C606.

5. North RA, Surprenant A. Pharmacology of cloned P2X receptors. Annu Rev Pharmacol Toxicol. 2000; $40: 563-580$.

6. Ralevic V, Burnstock G. Receptors for purines and pyrimidines. Pharmacol Rev. 1998;50(3): 413-492.

7. von Kugelgen I, Wetter A. Molecular pharmacology of P2Y-receptors. Naunyn Schmiedebergs Arch Pharmacol. 2000;362(4):310-323.

8. Wong BW, Wong D, McManus BM. Characterization of fractalkine (CX3CL1) and CX3CR1 in human coronary arteries with native atherosclerosis, diabetes mellitus, and transplant vascular disease. Cardiovasc Pathol. 2002;11(6):332-338.

9. Yoneda O, Imai T, Goda S, et al. Fractalkinemediated endothelial cell injury by NK cells. $J / m$ munol. 2000;164(8):4055-4062.

10. Bolovan-Fritts CA, Spector SA. Endothelial damage from cytomegalovirus-specific host immune response can be prevented by targeted disruption of fractalkine-CX3CR1 interaction. Blood. 2008; 111(1):175-182.

11. Umehara H, Bloom E, Okazaki T, Domae N, Imai T. Fractalkine and vascular injury. Trends Immunol. 2001;22(11):602-607.

12. Fong AM, Robinson LA, Steeber DA, et al. Fractalkine and CX3CR1 mediate a novel mechanism of leukocyte capture, firm adhesion, and activation under physiologic flow. J Exp Med. 1998; 188(8):1413-1419.

13. Pastore S, Mascia F, Gulinelli S, et al. Stimulation of purinergic receptors modulates chemokine expression in human keratinocytes. J Invest Dermatol. 2006;127(3):660-667.
14. Grynkiewicz G, Poenie M, Tsien RY. A new generation of $\mathrm{Ca} 2+$ indicators with greatly improved fluorescence properties. J Biol Chem. 1985; 260(6):3440-3450.

15. Zsembery A, Boyce AT, Liang L, Peti-Peterdi J, Bell PD, Schwiebert EM. Sustained calcium entry through P2X nucleotide receptor channels in human airway epithelial cells. J Biol Chem. 2003; 278(15):13398-13408.

16. Bazan JF, Bacon KB, Hardiman G, et al. A new class of membrane-bound chemokine with a CX3C motif. Nature. 1997;385(6617):640-644.

17. Garton KJ, Gough PJ, Blobel CP, et al. Tumor necrosis factor-alpha-converting enzyme (ADAM17) mediates the cleavage and shedding of fractalkine (CX3CL1). J Biol Chem. 2001; 276(41):37993-38001.

18. Hundhausen C, Misztela D, Berkhout TA, et al. The disintegrin-like metalloproteinase ADAM10 is involved in constitutive cleavage of CX3CL1 (fractalkine) and regulates CX3CL1-mediated cell-cell adhesion. Blood. 2003;102(4):1186-1195.

19. Freissmuth M, Boehm S, Beindl W, et al. Suramin analogues as subtype-selective $\mathrm{G}$ protein inhibitors. Mol Pharmacol. 1996;49(4):602-611.

20. Soto F, Lambrecht G, Nickel P, Stühmer W, Busch AE. Antagonistic properties of the suramin analogue NF023 at heterologously expressed P2X receptors. Neuropharmacology. 1999;38(1): 141-149.

21. Kim YC, Camaioni E, Ziganshin AU, et al. Synthesis and structure-activity relationships of pyridoxal-6-arylazo-5prime-phosphate and phosphonate derivatives as $\mathrm{P} 2$ receptor antagonists. Drug Dev Res. 1998;45(2):52-66.

22. Grenegård $M$, Vretenbrand-Öberg $K$, Nylander $M$ et al. The ATP-gated P2X1 receptor plays a pivotal role in activation of aspirin-treated platelets by thrombin and epinephrine. J Biol Chem. 2008; 283(27):18493-18504.

23. King BF, Liu M, Townsend-Nicholson A, et al. Antagonism of ATP responses at P2X receptor subtypes by the $\mathrm{pH}$ indicator dye, Phenol red. $\mathrm{Br} \mathrm{J}$ Pharmacol. 2005;145(3):313-322.

24. Moreschi I, Bruzzone S, Nicholas RA, et al. Extracellular NAD+ is an agonist of the human P2Y11 purinergic receptor in human granulocytes. J Biol Chem. 2006;281(42):31419-31429.
25. Yoneda O, Imai T, Nishimura M, et al. Membranebound form of fractalkine induces IFN-gamma production by NK cells. Eur J Immunol. 2003; 33(1):53-58.

26. Burnstock $\mathrm{G}$. Vessel tone and remodeling. Nat Med. 2006;12(1):16-17.

27. Kansas GS, Wood GS, Tedder TF. Expression, distribution, and biochemistry of human CD39: role in activation-associated homotypic adhesion of lymphocytes. J Immunol. 1991;146(7):22352244.

28. Kaczmarek E, Koziak K, Sevigny J, et al. Identification and characterization of CD39/vascular ATP diphosphohydrolase. J Biol Chem. 1996;271(51): 33116-33122.

29. Abbracchio MP, Burnstock G, Boeynaems JM, et al. International Union of Pharmacology LVIII. Update on the P2Y G protein-coupled nucleotide receptors: from molecular mechanisms and pathophysiology to therapy. Pharmacol Rev. 2006;58(3):281-341.

30. Schnurr M, Toy T, Stoitzner P, et al. ATP gradients inhibit the migratory capacity of specific human dendritic cell types: implications for P2Y11 receptor signaling. Blood. 2003;102(2):613-620.

31. Swennen EL, Bast A, Dagnelie PC. Immunoregulatory effects of adenosine 5 '-triphosphate on cytokine release from stimulated whole blood. Eur $J$ Immunol. 2005;35(3):852-858.

32. Wilkin F, Stordeur P, Goldman M, Boeynaems JM, Robaye B. Extracellular adenine nucleotides modulate cytokine production by human monocyte-derived dendritic cells: dual effect on IL-12 and stimulation of IL-10. Eur J Immunol. 2002; 32(9):2409-2417.

33. Marteau F, Communi D, Boeynaems JM, Suarez Gonzalez N. Involvement of multiple P2Y receptors and signaling pathways in the action of adenine nucleotides diphosphates on human monocyte-derived dendritic cells. J Leukoc Biol. 2004;76(4):796-803.

34. Vaughan KR, Stokes L, Prince LR, et al. Inhibition of neutrophil apoptosis by ATP is mediated by the P2Y11 receptor. J Immunol. 2007;179(12):85448553.

35. Moreschi I, Bruzzone S, Bodrato N, et al. NAADP + is an agonist of the human P2Y11 purinergic receptor. Cell Calcium. 2008;43(4):344355. 